\title{
ANALISIS WACANA CERITA RAKYAT SUMBAWA: KAJIAN STRUKTURAL DAN NILAI EDUKATIF
}

\author{
Rusmin Nurjadin \\ Program Studi Sastra Indonesia, Fakultas Ilmu Budaya \\ Institut Ilmu Sosial dan Ilmu Budaya Samawa Rea \\ e-mail: nurjadin.rusmin@gmail.com
}

\begin{abstract}
Abstrak
Penelitian ini adalah sebuah studi untuk mendeskripsikan struktur cerita dan nilai edukatif yang terdapat di dalam cerita rakyat Sumbawa. Cerita rakyat yang digunakan dalam penelitian yakni: (1) "Tanjung Menangis", (2) "Buen Lajendre", (3) "Sari Bulan". Penelitian ini menggunakan metode kualitatif deskriptif dengan analisis isi (content analysis) yang berfokus pada satu sasaran (subjek), yaitu cerita rakyat Sumbawa. Pengumpulan data dilakukan dengan studi pustaka dan wawancara sejumlah narasumber.Wacana dianalisis menggunakan teknik cuplikan (sampling) yaitu dengan teknik purposive sampling. Data kemudian dianalisis dengan pendekatan struktural dan analisis model interaktif (interactive model of analysis).Hasil penelitian menunjukkan struktur yang sederhana dan amanat yang terkandung dalam cerita rakyat Sumbawa cukup bervariasi. Nilai edukatif yang terdapat di dalam ketiga cerita rakyat Sumbawatersebut antara lain nilai edukatif moral, nilai edukatif adat (tradisi), nilai edukatif agama (religi), nilai edukatif sejarah (historis) dan nilai kepahlawanan.
\end{abstract}

Kata kunci: analisis wacana, cerita rakyat, Sumbawa, nilai edukatif, kajian struktural.

\section{A. PENDAHULUAN}

Identitas kebangsaan merupakan salah satu hal yang terancam ketika arus globalisasi masuk ke dalam Indonesia (UPI, 2017). Budaya kebangsaan yang berasal dari kumpulan budaya lokal dikhawatirkan akan mulai terkikis dari generasi muda (Tirtaharja, 2001). Hal ini akan menjadi ironi ketika rendahnya atensi generasi muda pada budaya bangsa berbanding terbalik dengan tingginya nilai-nilai sarat makna yang terdapat didalamnya.

Berpijak pada hal tersebut, bangsa Indonesia seyogyanya perlu meningkatkan kekuatan budaya yang dimiliki serta meningkatkan pengetahuan masyarakat akan budaya bangsa, khususnya pada generasi muda agar tetap memiliki identitas bangsa (UPI, 2017). Indonesia membutuhkan sebuah sistem yang dapat menuntun masyarakat agar dapat menemukan kembali kekuatan budaya yang pernah dimiliki. Sistem tersebut dapat berupa pola-pola dasar untuk mengarahkan paradigmaberpikir yang tidak hanya ditekankan pada sisi kognitif namun juga penekanan pada sisi afektif yaitu dengan pembangunan paradigma berpikir yang berdasar pada moralitas dan ketuhanan yang merupakan dasar dari kebuyaan Indonesia. Hal tersebut dapat tereksplorasi dari dimensi pendidikan. 
Pengeksplorasian moralitas dan ketuhanan dalam dimensi pendidikan dapat dilakukan melalui pengkajian sastra. Sastra Indonesia memungkinkan proses pengkajian nilai-nilai sosial, budaya, agama serta nilai-nilai kemanusiaan yang dapat mengantarkan pembaca pada kearifan dan kebijaksanaan yang telah menjadi pokok dari identitas bangsa Indonesia sejak dahulu kala. Hal ini senada dengan pendapat Kusman (1999) yang mengungkapkan bahwa karya sastra sesungguhnya merupakan kristalisasi nilai-nilai dari suatu masyarakat.

Cerita rakyat sebagai karya sastra yang sarat budaya bangsa mengandung kekayaan nilai di dalamnya. Cerita rakyat Tanjung Menangis, Buen Lajendre dan Sari Bulan sebagai tiga dari sekian banyak cerita rakyat Sumbawa dipercaya juga mengandung kekuatan nilai edukatif. Untuk mengetahui nilai-nilai edukatifyang terdapat didalam ketiga cerita rakyat tersebut, peneliti melakukan kajian terhadap struktur cerita rakyat Tanjung Menangis, Buen Lajendre dan Sari Bulan. Penelitian analisa struktur dan nilai edukatif terhadap ketiga cerita rakyatbelum pernah dilakukan sebelumnya. Hasil dari penelitian dapat memperkaya khasanah pengetahuan struktur cerita dan nilai edukatif dalam cerita rakyat Sumbawa, serta dapat dijadikan rekomendasi kajian cerita rakyat dalam dunia pendidikan.

\section{B. KAJIAN TEORI}

Kata "wacana" berdasarkan morfologi bahasa sansekerta dapat diartikan sebagai 'perkataan’ atau 'tuturan’ (Mulyana, 2005). Menurut Hasan Alwi, dkk. (1993), wacana bermakna rentetan kalimat yang bertautam sehingga terbentuk makna yang memiliki keserasian antar kalimat. Dalam Kamus Linguistik (Gramedia, 2011), Harimurti Kridalaksana (2011) menyebutkan pengertian dari wacana, "Wacana adalah satuan bahasa terlengkap, dalam hierarki gramatikal merupakan satuan gramatikal tertinggi atau terbesar. Wacana ini direalisasikan dalam bentuk karangan yang utuh (novel, buku, seri ensiklopedia, dan sebagainya), paragraf atau kata yang membawa amanat yang lengkap".

Menurut Sumarlam (2013), wacana dapat dikategorikan berdasar bahasa, media pengungkapan, jenis pemakaian, serta bentuk, cara dan tujuan pemaparannya. Berdasarkan klasifikasi yang diterangkan oleh Sumarlam, maka disimpulkan cerita rakyat yang digunakan dalam penelitian ini secara bahasa masuk ke dalam wacana bahasa lokal. Berdasarkan media yang digunakan dalam pemaparan, cerita rakyat yang digunakan dapat tergolong ke dalam wacana tulis maupun lisan. Berdasar sifat atau jenis pemakaian, dikategorikan ke dalam wacana dialog. Berdasar bentuk wacana termasuk ke dalam wacana prosa. Sedangkan berdasar cara dan tujuan pemaparan, maka cerita rakyat yang diangkat dalam penelitian ini merupakan wacana narasi. 
Rusyana (1981) menyatakan bahwa cerita rakyat adalah sebuah wacana yang telah lama hidup dalam sebuah tradisi masyarakat yang kemudian berkembang dan menyebar secara lisan dari generasi ke generasi. Bascom (Danandjaja, 2002) membagi kategori cerita rakyat menjadi tiga, yakni: (1) Mite, (2) Legenda, dan (3) Dongeng. Mite merupakan sastra berupa prosa yang berkembang di tengah masyarakat dan dipercaya benar-benar terjadi oleh masyarakat, tokoh yang terdapat di dalam Mite adalah dewa atau makhluk setengah dewa dengan latar tempat yang berbeda dengan dunia yang kita kenal serta memiliki latar waktu di masa lampau. Legenda adalah sebuah prosa rakyat yang dipercaya benar-benar terjadi, dengan tokoh manusia meski kadang disertai dengan sifat yang luar biasa dengan latar tempat yang sama seperti dunia yang kita kenal. Sedangkan dongeng adalah sebuah prosa rakyat yang tidak dianggap benar-benar terjadi serta tidak memiliki keterikatan latar tempat dan waktu. Cerita rakyat yang digunakan dalam penelitian ini termasuk ke dalam cerita rakyat legenda.

Cerita rakyat sebagai karya sastra memiliki unsur intrinsik yang membangun karya sastra serta yang akan dijumpai saat membaca karya sastra tersebut. Unsur intrinsik yang membangun cerita yakni (1) tema, (2) tokoh dan penokohan, (3) alur, (4) latar, dan (5) amanat (Nurgiyantoro, 2010). Pengertian tema oleh Zulfanur adalah ide pokok yang diperbincangkan dalam wacana yang tidak disebutkan secara tersurat oleh penulis namun dapat ditemukan oleh pembaca setelah membaca keseluruhan cerita (1997). Tokoh adalah pelaku cerita yang membawa watak-watak (penokohan) sehingga pembaca dapat mengikuti jalan sebuah cerita dan mengalami pengalaman batin seperti yang dialami tokoh (Wahid, 2004), sedangkan penokohon adalah watak atau sikap batin yang dibawa oleh masing-masing tokoh yang membedakannya dari tokoh yang lain(Nursisto, 2000). Alur adalah susunan cerita yang bertahap yang dihadirkan oleh tokoh-tokoh di dalam cerita (Aminuddin, 2004). Latar merupakan landasan atau tumpuan dari cerita yang terkait tempat, waktu dan lingkungan sosial dari peristiwa-peristiwa yang terdapat di dalam cerita (Abrams dalam Wahid, 2004). Sedangkan amanat menurut Sudjiman adalah pesan atau nilai moral yang tersimpan di dalam cerita yang bermaksud disampaikan oleh pengarang (Zulfahnur, 1997).

Ahmadi dan Unbiyati (1991) mengemukakan bahwa nilai merupakan sesuatu yang abstrak namun secara fungsional digunakan sebagai landasan untuk membedakan yang satu dengan lainnya. Nilai juga bersifat 'objektif' jika keberadaannya, maknanya dan validitasnya tergantung pada respon subjek yang memberikan penilaian, dengan tidak mempertimbangkan apakah itu psikis atau fisis (Frondizi, 2001). 
Pengertian dari nilai sastra adalah kebaikan yang terkandung dalam sebuah karya sastra bagi kehidupan. Setiap karya sastra yang baik akan memiliki nilai-nilai luhur yang dapat mendidik dan menggugah hati pembaca. Nilai edukatif yang dapat mendidik pembaca tersebut yakni (1) nilai moral, (2) nilai adat, (3) nilai agama/religius dan (4) nilai sejarah (Waluyo, 1990). Moral adalah sebuah kondisi kesesuaian antara perbuatan dan norma hukum batiniah yang dipandang wajib, nilai tersebutseringkali dikaitkan dengan perbuatan, sikap, kewajiban, budi pekerti, asusila, dll (Suseno, 1993). Nilai moral yang terdapat di dalam cerita biasanya berupa saran moral yang bersifat praktis. Pandangan mengenai moral biasanya hadir sebagai buah dari pandangan hidup pribadi, serta pandangan hidup bangsanya (Nurgiyantoro, 2009). Nilai adat adalah sebuah wujud ideal dari sebuah kebudayaan yang digunakan sebagai pengukur kelakuan (Koenjtjaraningrat, 2013). Nilai agama/religius merupakan perwujudan dari kepercayaan manusia akan sifat-sifat Tuhan dan alam gaib beserta segala nilai, norma dan ajaran yang diajarkan dari agama/religi bersangkutan (Koentjaningrat, 2013). Nilai edukatif sejarah (historis) adalah nilai yang merefleksikan sejarah kehidupan masyarakat lokal dan bangsa. Nilai edukatif sejarah dalam sebuah cerita memungkinkan pembaca dapat menelusuri peristiwa bersejarah di masa lampau (Abdullah, 2004).

\section{METODE PENELITIAN}

Penelitian dilaksanakan dengan menggunakan metode kualitatif deskriptif dan analisis isi dilakukan proses pengidentifikasian, pengkajian dan pendeskripsian struktur 3 cerita rakyat Sumbawa yang meliputi tema, alur, tokoh, latar dan amanat serta nilai edukatif (pendidikan). Menurut Moch. Nazir (2011), metode deskriptif memiliki tujuan untuk mendeskripsikan gambaran hal yang diteliti secara sistematis, faktual dan akurat. Metode kualititatif deskriptif memungkinkan peneliti melakukan analisis mendalam terhadap struktur dan nilai edukatif cerita rakyat yang diteliti.

Cerita rakyat Sumbawa yang digunakan dalam penelitian dipilih secara purposive sampling yakni cerita (1) “Tanjung Menangis", (2) "Buen Lajendre", dan (3) "Sari Bulan". Metode purposive sampling adalah teknik penentuan sampel penelitian dengan pertimbangan-pertimbangan tertentu dari peneliti (Sugiyono, 2016). Data dari penelitian didapatkan dengan melakukan komunikasi dengan Pemda Kabupaten Sumbawa, Kantor Dinas Pariwisata Kabupaten Sumbawa, Kantor Arsip dan Perpustakaan Daerah Sumbawa terkait arsip cerita rakyat tersebut. Selanjutnya peneliti memilih dan memilah data yang diperlukan dalam proses analis wacana cerita rakyat. 
Instrumen yang digunakan dalam penelitian yakni handphone, komputer, informan (Kabid Pendidikan dan Kebudayaan Dinas Pariwisata Sumbawa, Pegawai kantor Arpusda Sumbawa, Pimred Koran Gaung Sumbawa, Redaksi Media Online pulausumbawanews.com, sejarawan, seniman) dan tabel analisis data. Tabel analisis data digunakan untuk memudahkan peneliti dalam menganalisis dan mempresentasikan struktur serta nilai edukatif dalam wacana cerita rakyat Sumbawa.

Metode yang digunakan dalam menganalisis data yakni dengan metode analysis interactive Miles dan Huberman, yaitu dengan membagi tahapan analisis data menjadi tahap pengumpulan data (data collection), reduksi data (data reduction), penyajian data (data display) dan penarikan kesimpulan (conclution). Data yang didapatkan dari hasil wawancara dengan beberapa sumber informan serta dokumen wacana cerita rakyat dikumpulkan dan dipelajari, tahapan ini masuk dalam tahap pengumpulan data. Tahap reduksi data merupakan tahapan analisis yang lebih mendalam dimana terdapat proses pengkategorisasian serta pembuangan data-data yang tidak dibutuhkan dalam penelitian. Tahap penyajian data merupakan tahapan dimana informasi data yang dibutuhkan telah diorganisasi sedemikian rupa hingga memungkinkan untuk menarik kesimpulan (Miles and Huberman, 2007). Tahapan terakhir yaitu tahapan penarikan kesimpulan dilakukan dengan memerhatikan polapola, pernyataan-pernyataan, konfigurasi, sebab-akibat dan berbagai preposisi (Harsono 2008).

\section{HASIL DAN PEMBAHASAN}

\section{Kajian Struktural}

Cerita rakyat yang dikaji pada penelitian ini adalah cerita rakyat yang berasal dari Sumbawa, yakni cerita rakyat Tanjung Menangis, Buen Lajendre dan Sari Bulan. Tanjung Menangis merupakan cerita rakyat yang berkisah tentang seorang mubaligh Islam dari kerajaan Gowa Tallo Makassar yang bermaksud menolong menyembuhkan penyakit putri dari kerajaan Sumbawa. Putri tersebut bernama Lala Intan Bulaeng yang cantik rupawan namun didera penyakit lepra yang tidak juga ditemukan obatnya. Sedang sang mubaligh bernama Maulana Malik Zaenal Abidin, pangeran dari kerajaanGowa Tallo yang tampan, alim, gagah dan rendah hati. Ia mengikuti sayembara yang diadakan kerajaan Sumbawa guna menyembuhkan penyakit Lala Intan Bulaeng dengan menyamar menjadi sandro atau tabib tua yang berpakaian lusuh yang dikirimkan sebagai perwakilan sandro dari kerajaan Gowa Tallo. Sayembara tersebut menawarkan imbalan kepada sandro yang mampu memberi kesembuhan yakni akan dikawinkan dengan Putri Lala Intan Bulaeng dan menggantikan 
posisi sang Raja memimpin kerajaan Sumbawa. Banyak sandro dan pangeran yang datang dari negeri seberang namun tak satupun yang dapat menyembuhkan sang putri. Hingga akhirnya datanglah Zaenal Abidin dengan penyamarannya. Pada awal kehadirannya, semua menyangsikan kemampuan Zaenal Abidin karena penampilannya. Zaenal Abidin kemudian menjalankan prosesi penyembuhan putri Lala Intan Bulaeng berupa pengajaran syariatsyariat agama Islam. Tempat penyembuhan Lala Intan Bulaeng berlokasi di sebuah lereng bukit yang di bawahnya terdapat sebuah mata air. Dalam proses pengobatan Lala Intan Bulaeng pula, Zaenal Abidin membuat mata air baru di atas lereng dan kemudian disebut dengan Ai Awak yang berarti air permulaan. Setelah melewati pengobatan yang sebenarnya berisi pengajaran nilai-nilai agama/religius Islam, putri Lala Intan Bulaeng pun sembuh. Tiba masa penjemputan, Zaenal Abidin didera fitnah dari kerajaan maupun dari masyarakat. Ia pun memutuskan pergi kembali ke negerinya. Putri Lala Intan Bulaeng yang telah jatuh hati pada Zaenal Abidin melarikan diri mengejar Zaenal Abidin namun tak terkejar, kapal pinisi milik kerajaan Zaenal Abidin telah sampai ke tengah lautan. Putri Lala Intan Bulaeng pun menangis di ujung timur Tanjung Menangis hingga akhirnya ditemukan telah meninggal, terjatuh dari ujung Tanjung (Zulkarnain, 2012).

Buen Lajendre merupakan cerita rakyat yang diawali dengan penceritaan perjodohan yang dilakukan oleh Dea Raden Hung dan Raden Mangi terhadap putri dan putra mereka sejak masih kecil. Putri Dea Raden Hung yang bernama Lala Ila dan putra Raden Mangi yang bernama Lalu Mangi bahkan tidak pernah mengetahui mengenai perjodohan tersebut. Namun keduanya justru saling mencintai saat tumbuh dewasa. Lala Ila yang dikenal sebagai bunga desa yang masyhur terdengar kecantikannya sampai keluar desa mengundang perhatian Lalu Mangi hingga merantau ke desa Lala Ila. Disanalah mereka saling mengenal dan memadu kasih. Dibantu oleh pamannya yang tinggal di desa tersebut, Lalu Mangi kemudian melamar Lala Ila. Saat mempersiapkan pernikahannya, Lalu Mangi berkenalan dengan Daeng Jage seorang pedagang dari Ujung Pandang. Selain berjualan kain dan minyak wangi, rupayanya Daeng Jage diam-diam juga menjadi pengedar candu (opium) pada masyarakat Sumbawa. Ia melakukan tipu muslihat dan bujuk rayu hingga akhirnya mengubah Lalu Mangi menjadi pecandu. Lama kelamaan Lalu Mangi menjadi kurus, malas dan menghabiskan uang persiapan pernikahannya demi membayar hutang candunya pada Daeng Jage. Hutang yang semakin banyak membuat Lalu Mangi akhirnya menukar Lala Ila kekasihnya sebagai penebus hutang disertai tumpukan tunjangan uang. Lalu Mangi pun melakukan tipuan pada Lala Ila hingga Lala Ila terjebak naik ke perahu Daeng Jage ditukar dengan sejumlah uang. Sesaat timbul sesal di hati Lalu Mangi saat menyadari perbuatannya telah salah, namun Lalu 
Mangi tetap tidak mampu berbuat apa-apa. Lala Ila meronta dan menangis hingga air laut Buen Lajendre berkecamuk, hujan deras turun dan angin kencang menghempas perahu mereka ke atas karang hingga perahu kandas tersebut pun berubah menjadi salah satu pulau kecil di Selat Alas Sumbawa. Dan hingga kini, air Buen Lajendre yang dipercaya sebagai jelmaan air mata Lalu Mangi dan Lala Ila tidak pernah mongering (Proyek Penerbitan dan Pencatatan Kebudayaan Daerah, 1981).

Cerita rakyat Sari Bulan mengisahkan tentang seorang pangeran bernama Datu Panda'i yang berlayar keluar dari kerajaannya demi mencari Sari Bulan, wanita cantik yang muncul di dalam mimpinya. Bertahun ia berlayar dari pulau ke pulau untuk mencari Sari Bulan hingga pencariannya berbuah manis. Datu Panda'i akhirnya menemukan Sari Bulan saat singgah ke pelabuhan di sebuah pulau. Datu Panda'i meminang Sari Bulan dan hidup bahagia bersama keluarga Sari Bulan. Suatu hari Datu Panda'i meminta ijin kepada keluarga besar Sari Bulan untuk membawa istrinya yang tengah hamil besar pulang ke kerajaannya. Permintaan tersebut mendapat keridhoan dari keluarga Sari Bulan dengan pesan dari kedua orang tua untuk tidak mendekati bahkan mampir di Pulau Dewa. Dipercayai oleh masyarakat bahwa Pulau Dewa adalah tempat tinggal para jin, setan dan iblis. Datu Panda'i menyanggupi. Namun saat di perjalanan, Datu Panda'i tidak kuasa untuk menolak permintaan Sari Bulan yang meminta daging menjangan dari Pulau Dewa. Mereka pun berlabuh. Datu Panda'i dan seluruh awak kapal turun mencari menjangan, sedang Sari Bulan menunggu di atas kapal seorang diri. Tidak lama muncullah Kunti, salah satu pelayan iblis yang ingin merebut posisi Sari Bulan sebagai istri Datu Panda'i. Ia menyerang Sari Bulan hingga kedua matanya terlepas dan Sari Bulan menjadi buta. Setelah menjatuhkan Sari Bulan ke laut, Kunti segera mengenakan pakaian dan perhiasan Sari Bulan di dalam perahu. Sekembalinya dari pencarian daging menjangan, Datu Panda'i kaget menemukan istrinya telah berubah menjadi buruk rupa, ia mengira Kunti adalah istrinya yang terkena kutukan Pulau Dewa. Ia menerima kesalahannya dan membawa pulang istrinya meski dengan hati yang sedih, malu dan penuh sesal. Tidak disadarinya bahwa Sari Bulan ternyata masih hidup dan diselamatkan oleh kerang raksasa hingga ke tepian pantai yang letaknya cukup jauh dari kerajaan Datu Panda'i. Setelah menyelamatkan Sari Bulan, kerang besar tersebut mati. Cangkangnya digunakan oleh Sari Bulan untuk melahirkan dan membesarkan anaknya yang ia beri nama Aipad. Sari Bulan menghidupi kehidupan mereka dengan matila (memintaminta). Suatu hari saat Aipad telah besar, ia melakukan matila pada seorang nelayan. Merasa kasihan pada Aipad, nelayan memberi ikan terbesarnya kepada Aipad. Saat membelah ikan tersebut, Aipad menemukan kedua mata ibunya hingga Ibunya bisa melihat kembali. Demi 
membalas kebaikan nelayan bernama Tangko, Aipad dan Ibunya pun menawarkan diri menjadi abdi Tangko yang disambut baik oleh Tangko. Tangko dan istrinya yang tidak memiliki anak membesarkan Aipad dengan kasih sayang bahkan memberikan Aipad kuda pacuan yang kuat dan mendukungnya untuk mengikuti sayembara kuda yang diadakan kerajaan Datu Panda'i. Dalam pacuan kuda tersebut, Aipad berhasil berkali-kali menang hingga akhirnya berhadapan dengan lawan terakhir yakni sang raja yang tidak lain adalah Datu Panda'i. Aipad memenangkan pacuan tersebut dan mendapatkan hadiah dari sayembara yakni menerima mahkota kerajaan milik Datu Panda'i. Saat menemani Aipad dalam penyerahan mahkota kerajaan, Sari Bulan dan Datu Panda'i bertemu, mereka terkejut dan tak kuasa menahan tangis. Datu Panda'i baru menyadari bahwa Aipad adalah putranya dan dari Sari Bulan, ia pun mengetahui siasat yang selama ini dijalankan Kunti. Aipad yang kemudian memegang mahkota kerajaan menghukum Kunti dengan mengurungnya di dalam sumur yang sangat dalam. Dan untuk membalas budi nelayan Tangko, ia pun mengganti nama kerajaan yang ia pegang menjadi kerajaan Tangko (Proyek Penerbitan dan Pencatatan Kebudayaan Daerah, 1981).

Wacana cerita rakyat Tanjung Menangis, Buen Lajendre dan Sari Bulan tersebut kemudianpeneliti analisia secara struktural dengan mengkaji unsur-unsur intrinsik yang terkandung di dalamnya, yakni tema, alur, tokoh/penokohan, latar, dan amanat (Nurgiyantoro, 2009).Wacana dikaji secara struktural dengan unsur-unsur intrinsik tersebut dan dimasukkan ke dalam tabel analisis seperti pada table 1.

Tabel 1 Analisis Struktur Cerita Rakyat Sumbawa

\begin{tabular}{llll}
\hline \multicolumn{1}{c}{ Kajian } & & \multicolumn{3}{c}{ Cerita Rakyat } & \\
\cline { 2 - 4 } Struktural & \multicolumn{1}{c}{ Tanjung Menangis } & \multicolumn{1}{c}{ Buen Lajendre } & \multicolumn{1}{c}{ Sari Bulan } \\
& Legenda keagamaan & Legenda setempat, asal & Legenda Setempat, asal \\
& & muasal Buen Lajendre & $\begin{array}{l}\text { muasal Kerajaan } \\
\text { Tangko. }\end{array}$ \\
Tokoh / & Mubaligh (Maulana & Putri keturunan & Putra Mahkota kerajaan \\
Penokohan & Malik Zaenal Abidin), & bangsawan (Lala Ila), & di timur Sumbawa (Datu \\
& putri raja (Lala Intan & putra abdi kerajaan & Panda'i), putri jelita dari \\
& Bulaeng), raja, & (Lalu Mangi), Orang tua & negeri seberang (Sari \\
& permaisuri, abdi raja, & Lalu Mangi (Raden & Bulan), pelayan jin di \\
& inang pengasuh, pasukan & Magi dan istri), ayah & Pulau Dewa, anak Sari \\
\hline
\end{tabular}




\begin{tabular}{|c|c|c|c|}
\hline & istana & Lala Ila (Datu Raden & Bulan dan Datu Panda'i \\
\hline & & $\begin{array}{l}\text { Ilung), pengawal Lalu } \\
\text { Mangi (Salampe), } \\
\text { Paman Lalu Mangi (Dea } \\
\text { Angge dan istri), } \\
\text { saudagar kain dan opium } \\
\text { (Daeng Joge), Inang } \\
\text { pengasuh Lala Ila (Nini } \\
\text { Saje) }\end{array}$ & $\begin{array}{l}\text { (Aipad), nelayan yang } \\
\text { baik hati, Raja / orang } \\
\text { tua Datu Panda'I, Ayah } \\
\text { Sari Bulan, armada Datu } \\
\text { Panda'i, gadis-gadis di } \\
\text { desa Sari Bulan, } \\
\text { masyarakat kerajaan } \\
\text { Sumbawa. }\end{array}$ \\
\hline Alur & Backtracking & Progresif & Progresif \\
\hline Latar & $\begin{array}{l}\text { Latar tempat : Tanjung } \\
\text { Menangis }\end{array}$ & $\begin{array}{l}\text { Latar tempat: Kalampet } \\
\text { (wilayah di kerajaan } \\
\text { Sumbawa), kebun dan } \\
\text { Buen Lajendre. }\end{array}$ & $\begin{array}{l}\text { Latar tempat: kerajaan di } \\
\text { timur Sumbawa, pulau- } \\
\text { pulau kecil, pelabuhan } \\
\text { dan dermaga serta } \\
\text { Kerajaan Tangko yang } \\
\text { kini lokasinya termasuk } \\
\text { dalam kecamatan } \\
\text { Empang }\end{array}$ \\
\hline Amanat & $\begin{array}{l}\text { 1. Pengenalan tempat di } \\
\text { Sumbawa yang sarat } \\
\text { akan sejarah } \\
\text { perkembangan } \\
\text { masuknya Islma. } \\
\text { 2. Pesan untuk } \\
\text { melestarikan tempat- } \\
\text { tempat bersejarah dan } \\
\text { religius di Sumbawa } \\
\text { 3. Pesan untuk } \\
\text { senantiasa menjadi } \\
\text { orang yang dapat } \\
\text { dipercaya. } \\
\text { 4. Pesan untuk tidak } \\
\text { menilai seseorang dari }\end{array}$ & $\begin{array}{l}\text { 1. Seseorang harus } \\
\text { memiliki sikap dan } \\
\text { pendirian kuat hingga } \\
\text { tidak mudah tergoda } \\
\text { pada hal-hal buruk, } \\
\text { seperti Lalu Mangi yang } \\
\text { tergoda untuk } \\
\text { menggunakan opium } \\
\text { hingga mengorbankan } \\
\text { kekasihnya dalam } \\
\text { banyak hal termasuk } \\
\text { nyawa. } \\
\text { 2. Waspada terhadap } \\
\text { berbagai tipu muslihat } \\
\text { 3. Pengenalan terhadap }\end{array}$ & $\begin{array}{l}\text { 1. Pesan bahwa } \\
\text { kebenaran akan } \\
\text { mengalahkan } \\
\text { kebatilan/kejahatan. } \\
\text { 2. Kecurangan akan } \\
\text { mengalami kekalahan } \\
\text { pada akhirnya. } \\
\text { 3. Ketulusan hati untuk } \\
\text { menolong sesama akan } \\
\text { berbuah kebaikan pula } \\
\text { suatu saat nanti bahkan } \\
\text { melebihi pemberian } \\
\text { yang kita lakukan. } \\
\text { 4. Hal-hal yang merusak } \\
\text { akhlak, membuang harta }\end{array}$ \\
\hline
\end{tabular}




\begin{tabular}{lll}
\hline kondisi fisik namun juga & sejarah Buen Lajendre di & sia-sia hanya akan \\
menilai dari kepribadian. & Desa Lantung Sumbawa & mendekatkan diri pada \\
5. Berhati-hati dalam & serta ajakan untuk & kekufuran. \\
mengambil keputusan & melestarikannya. & \\
dengan & \\
mempertimbangkan & & \\
berbagai sudut pandang & & \\
dan kepentingan banyak & & \\
pihak. & & \\
\hline
\end{tabular}

Berdasarkan penelitian yang dilakukan,tema ketiga cerita rakyat tersebut dikategorikan ke dalam tema cerita rakyat legenda. Menurut Hutomo (1991), legenda adalah cerita yang dipercaya oleh masyarakat mengandung peristiwa sejarah. Sedangkan James Danadjaja (1984) menegaskan bahwa legenda dinilai sebagai sejarah kolektif, meski "sejarah" tersebut sejarah tertulis yang seringkali mengalami distorsi hingga menyebabkan isinya kemungkinan jauh berbeda dengan aslinya.

Danandjaja (1984) juga mengklasifikasi legenda menjadi empat yakni: (1) legenda keagamaan (religious legend), (2) legenda alam gaib (supranatural legend), (3) legenda perseorangan (personal legend) dan (4) legenda setempat (local legend). Dari analisa mendalam tersebut, Buen Lajendre dan Sari Bulan disimpulkan memiliki tema legenda setempat karena memiliki inti cerita pengisahan asal muasal suatu tempat (Buen Lajendre) dan asal muasal Kerajaan Tangko (Sari Bulan), sedangkan cerita rakyat Tanjung Menangis memiliki tema legenda keagamaan karena berisi cerita penyebaran ajaran Islam di kerajaan Sumbawa.

Ketiga cerita rakyat yang dikatakan sebagai legenda tersebut tersusun oleh tahapantahapan cerita yang disebut sebagai alur. Jabrohim (2003) mengemukakan bahwa cerita rakyat adalah rangkaian peristiwa yang disusun dengan dasar sebab-akibat. Susunan atau tahapan tersebut terdiri dari tahap awal yakni tahap perkenalan, tahap pertengahan yang berisi konflik dan tahap akhir atau tahap penyelesaian (Nugiyantoro, 2005). Jabrohim (2003) menambahkan bahwa terdapat empat jenis alur dari cerita antara lain: (1) alur maju (progresif) yaitu dimulai dari tahap awal cerita menuju ke tahap tengah dan diakhiri dengan tahap penutup, (2) alur mundur (regresif) yaitu berawal dari akhir cerita menuju ke tahap tengah dan diakhiri oleh tahap awal, (3) alur sorot balik (flashback) yaitu alur yang mirip 
dengan regresif namun diawali dengan teknik progresif dan (4) alur tarik balik (backtracking) yaitu alur yang progresif kemudian pada peristiwa tertentu cerita ditarik ke belakang namun kembali lagi ke progresif. Berdasarkan teori tersebut, cerita rakyat Tanjung Menangis memiliki jenis alur backtracking, sedangkan cerita Buen Lajendre dan Sari Bulan memiliki jenis alur yang sederhana yakni alur progresif.

Latar tempat bersejarah di Sumbawa menjadi latar yang ditonjolkan oleh ketiga cerita rakyat tersebut. Tanjung Menangis diceritakan dengan latar tempat Tanjung Menangis, dimana Lala Intan Bulaeng beradu menangisi kepergian Zaenal Abidin. Buen Lajendre memiliki latar tempat Kalampet, sebuah wilayah di kerajaan Sumbawa, serta kebun dan Buen Lajendre yakni mata air yang dikatakan sebagai penjelmaan air mata Lala Ila yang menangisi pengkhianatan Lalu Mangi. Cerita rakyat Sari Bulan menggambarkan latar kerajaan di timur Sumbawa, pulau-pulau kecil, pelabuhan dan dermaga, serta kerajaan Tangko tempatnya kini dikenal masuk ke dalam kecamatan Empang.Hal ini sesuai dengan pendapat Abrams (1981:175) dalam Nurgiyantoro (2009:216) bahwa latar dalam karya sastra merupakan landasan tumpu cerita yang berkaitan dengan tempat, waktu, dan lingkungan sosial dimana peristiwa-peristiwa itu terjadi.

Dalam kajian struktural tokoh/penokohan, Tanjung Menangis memiliki dua tokoh utama yakni seorang mubaligh bernama Maulana Malik Zaenal Abidin, putri raja bernama Lala Intan Bulaeng serta dibantu oleh tokoh lainnya yaitu raja, permaisuri, abdi-abdi raja, inang pengasuh Lala Intan Bulaeng, serta pasukan istana. Dari kisah ini terdapat sejumlah amanat diantaranya pengenalan tempat di Sumbawa yang sarat akan sejarah perkembangan masuknya Islam, pesan untuk melestarikan tempat-tempat bersejarah dan religius di Sumbawa, pesan untuk senantiasa menjadi orang yang dapat dipercaya, pesan untuk tidak menilai seseorang dari kondisi fisik namun juga menilai dari kepribadian, berhati-hati dalam mengambil keputusan dengan mempertimbangkan berbagai sudut pandang dan kepentingan banyak pihak.

Tokoh utama yang terdapat di dalam cerita Buen Lajendre yakni Putri keturunan bangsawan yaitu Lala Ila serta putra abdi kerajaan bernama Lalu Mangi. Tokoh lain yang terdapat di dalam cerita antara lain orang tua Lalu Mangi (Raden Magi dan istri), ayah Lala Ila (Datu Raden Ilung), pengawal Lalu Mangi (Salampe), Paman Lalu Mangi (Dea Angge dan istri), saudagar kain dan opium (Daeng Joge), dan inang pengasuh Lala Ila (Nini Saje).Tokoh-tokoh tersebut dikisahkan di dalam cerita rakyat Buen Lajendre dengan membawa amanat cerita yakni seseorang harus memiliki sikap dan pendirian kuat hingga tidak mudah tergoda pada hal-hal buruk seperti Lalu Mangi yang tergoda untuk 
menggunakan opium hingga mengorbankan kekasihnya dalam banyak hal termasuk nyawa, pesan untuk waspada terhadap berbagai tipu muslihat, hal-hal yang merusak akhlak serta membuang harta sia-sia hanya akan mendekatkan diri pada kekufuran, juga terdapat pengenalan terhadap sejarah Buen Lajendre di Desa Lantung Sumbawa serta ajakan untuk melestarikannya.

Seperti halnya kedua cerita rakyat lainnya, cerita Sari Bulan dibangun oleh dua tokoh utama yakni putra mahkota kerajaan di timur Sumbawa (Datu Panda'i), dan putri jelita dari negeri seberang (Sari Bulan). Tokoh lainnya yang membantu membangun cerita antara lain pelayan jin di Pulau Dewa, anak Sari Bulan dan Datu Panda'i bernama Aipad, nelayan yang baik hati bernama Tangko, Raja / orang tua Datu Panda'i, ayah dari Sari Bulan, armada Datu Panda'i, gadis-gadis di desa Sari Bulan, masyarakat kerajaan Sumbawa. Cerita ini mengandung amanat antara lain pesan bahwa kebenaran akan mengalahkan kebatilan/kejahatan, kecurangan akan mengalami kekalahan pada akhirnya, ketulusan hati untuk menolong sesama akan berbuah kebaikan pula suatu saat nanti bahkan melebihi pemberian yang kita lakukan.

Menurut Nurgiyantoro (2009), sebuah cerita dibangun oleh tokoh-tokoh yang membawa perwatakannya masing-masing hingga penulis dapat menyampaikan amanat di dalam cerita. Setiap cerita memiliki tokoh-tokoh yang diutamakan penceritaannya atau disebut sebagai tokoh utama dan tokoh-tokoh tambahan. Hal ini sesuai dengan temuan dari penelitian ini, bahwa ketiga cerita dibangun oleh tokoh-tokoh utama dan tokoh-tokoh tambahan. Tokoh-tokoh utama dan tambahan tersebut diperankan oleh manusia biasa, manusia dengan karakter luar biasa maupun makhluk gaib. Toko-tokoh tersebut merupakan ciri dari cerita rakyat bertema legenda (Danandjaja, 2002).

Amanat yang terdapat di dalam ketiga cerita ditangkap secara tersurat (eksplisit) dan tersirat (implisit). Amanat tersebut didapatkan melalui percakapan antar tokoh, melalui deskripsi langsung pengarang di dalam cerita, juga didapatkan melalui perenungan atau pemikiran terhadap apa yang terjadi di dalam cerita. Hal ini sejalan dengan pernyataan Esten (1978) bahwa di dalam amanat terlihat pandangan hidup dan cita-cita dari pengarang. Amanat tersebut disampaikan secara eksplisit maupun implisit. Teeuw (1983) mengungkapkan bahwa amanat berkaitan dengan makna yang khas, umum, subjektif hingga untuk mendapatkannya perlu dilakukan suatu proses penafsiran. 


\section{Nilai Edukatif}

Setiap karya sastra memiliki nilai sastra. Nilai sastra di dalam sebuah karya sastra adalah sebuah amanat atau pesan kebaikan bagi kehidupan(Waluyo, 1990). Amanat yangdibangun di dalam ketiga cerita rakyat disusun oleh nilai-nilai edukatif yang terkandung, yakni nilai moral, nilai adat/tradisi, nilai agama/religius, dan nilai sejarah(Waluyo, 1990).

Nilai moral dalam sebuah cerita umumnya adalah hasil pandangan hidup dari penulis cerita mengenai nilai-nilai kebenaran yang ingin ia sampaikan pada pembaca (Nurgiyantoro, 2009). Cerita Tanjung Menangis, Buen Lajendre dan Sari Bulan mengandung nilai moral. Nilai moral yang terkandung di dalam cerita Tanjung Menangisyaitu terdapat pada penggambaran watak Zaenal Abidin yang memiliki sikap sopan dan santun dalam bersikap maupun bertutur kata. Dapat terlihat dari kutipan: "Ampun tuanku, hamba tidak akan memakai ramuan akar-akar, kulit-kulit, dan batang-batang pohon. Daun pun tidak. Hamba mohon agar tuanku pasrah dan ikhlas serta yakin akan usaha yang hamba lakukan.". Nilai moral pada cerita Buen Lajendre terlihat melalui pendeskripsian awal mula sikap Lalu Mangi sebelum menjadi pecandu, yakni ia memiliki sikap hormat kepada orang tua dan berpamitan sebelum bepergian. Hal ini tercermin di dalam kutipan: "Hati-hati di jalan anakku. Bawalah azimat ini agar kalian tidak digigit ular berbisa atau disengat kalajengking." Sesudah itu Lalu Mangi bersujud di kaki Ibu Bapaknya.Cerita rakyat Sari Bulan mengandung nilai moral yang ditunjukkan pada penggambaran Aipad dan Sari Bulan yang memiliki sikap penuh syukur dan berupaya membalas budi baik pada orang yang telah memberikan bantuan. Nilai tersebut terdapat di dalam kutipan : "Setelah mengucapkan terima kasih kepada Tangko, Aipad pun segera berlari pulang untuk memberikan ikan tersebut kepada Ibunya. Konon, setelah ikan itu dibelah, Aipad menemukan kedua biji mata Ibunya di dalam perut ikan tersebut. Kedua biji mata itu kemudian dipasangkan kembali sehingga Ibunya dapat melihat seperti sedia kala. Dan, untuk membalas jasa baik nelayan tersebut, Aipad bersama Ibunya menawarkan diri untuk mengabdi kepada keluarga Tangko."

Nilai adat merupakan perwujudan kebudayaan yang digunakan masyarakatuntuk mengatur dan mengukur kelakuan manusia (Koentjaraningrat, 2013). Nilai adat yang tergambarkan dalam cerita Tanjung Menangis yakni penyebutan tradisi Maen-Asu (Berburu), tradisi yang dimunculkan dalam cerita sebagai bentuk hiburan kegemaran masyarakat dalam acara-acara yang melibatkan kejaraan. Tradisi ini disebutkan dalam kutipan: hasil-hasil hutan seperti madu dan menjangan menjadi pameran utama masyarakat dengan menyelenggarakan berbagai kegiatan menyambut rajanya. 'Maen-Asu' (berburu) adalah hiburan kegemaran rakyat pada masa itu. Ilmu berburu menjadi modal utama masyarakat 
dalam menyikapi alam lingkungannya masing-masing.Nilai adat cerita Buen Lajendre terkandung di dalam penggambaran tradisi menjodohkan anak-anak sejak kecil untuk mempererat kekerabatan antar dua keluarga. Nilai ini terdapat pada kutipan: ...Sewaktu kecil ia telah dipertunangkan dengan Lalu Mangi, putra Raden Mangi, yang tinggal di kampung Kalempet Sumbawa. Antara mereka terdapat hubungan itu. Maka dipertunangkanlah Lala Ila dan Lalu Mangi. Melalui hal inilah hubungan keluarga yang telah jauh menjadi dekat kembali. Ketika usia mereka meningkat remaja kedua anak itu tidak mengetahui pertunanganan mereka. Orang tua mereka tidak pernah menceritakannya.Pada cerita Sari Bulan, kutipan : Dalam usaha mencari puteri Sari Bulan, Datu Panda'I meminta izin kepada ayahandanya untuk mempersiapkan sebuah armada laut yang terdiri dari orang-orang gagah berani. Datu Panda'i sendiri akan menjadi pemimpinnya karena tidak mungkin armada akan memperoleh gadis yang dimaksud tanpa mengetahui wajah gadis yang dicari. Perjalanan armada pencari gadis Sari Bulan itu memakan waktu cukup lama. Puluhan kali mereka terpaksa menyinggahi pulau-pulau kecil karena kehabisan bekal air dan makanan.." adalah sebuah deskripsi nilai adat Sumbawa yaitu tradisi merantau dalam melakukan pencaharian maupun berbagai pencarian lainnya, termasuk pencarian calon istri.

Nilai agama/religius adalah nilai yang mendasari aktivitas manusia yang bersumber dari getaran jiwa keagamaan (Koentjaraningrat, 2009). Tata cara Zaenal Abidin ketika melaksanakan penyembuhan penyakit putri Raja dengan menggunakan ritual-ritual keagamaan syariat Islam adalah cerminan nilai agama/religius dalam cerita Tanjung Menangis. Hal tersebut dapat dilihat pada kutipan: "Setelah rukun Islam dan rukun iman dinda pahami dan hayati, maka nanti rukun tiga-belas dan sifat dua puluh akan menampakkan dirinya. Saat itulah akan saya cincang habis-habisan.” kata Zaenal Abidin dengan mantap. Dalam batin sang putri, istilah 'mencincang' adalah sebuah ungkapan yang bermakna menjelaskan secara rinci dan detil masalah-masalah agama dalam kaitannya dengan tubuh manusia-. Kutipan yang terdapat dalam Buen Lajendre yakni: "Kita cuma berikhtiar namun Tuhanlah yang menentukan berhasil tidaknya usaha dan ikhtiar itu" yang diucapkan oleh Dea Angge merupakan pencerminan dari nilai agama/religiusyang menggambarkan sikap usaha seorang manusia namun tetap pasrah pada ketetapan akhir dari Tuhan.Nilai agama/religius dari cerita Sari Bulan tercermin dari kondisi spritual masyarakat Sumbawa sebelum masuknya Islam yakni kepercayaan masyarakat Sumbawa untuk menyembah makhluk-makhluk ghaib atau disebut dengan kepercayaan animisme dengan memberikan sesajen-sesajen dan matra-matra sebagai upaya mewujudkan hajatnya. “...Puluhan kali mereka terpaksa menyinggahi pulau-pulau kecil karena kehabisan bekal air 
dan makanan. Entah berapa mantra yang sudah diucapkan dan berapa biaya telah dihamburkan untuk membuat sesajen di tempat-tempat keramat serta memohon berkah kepada arwah nenek moyang...".

Nilai edukatif sejarah dalam sastra adalah nilai yang menjelaskan sejarah kehidupan masyarakat lokal dan bangsa hingga pembaca dapat menelusuri peristiwa bersejarah di masa lampau (Abdullah, 2004). Dalam cerita Tanjung Menangis banyak kutipan yang mengandung nilai sejarah yang menggambarkan kondisi Sumbawa serta kerajaan Sumbawa pada masa itu, sebagai contoh pendeskripsian Kerajaan Sumbawa sebagai kerajaan yang aman dan tentram dengan Raja yang sangat arif dan bijaksana dalam memimpin pemerintahan. Kutipan yang mencerminkan nilai sejarah tersebut yakni pada kalimat : Rakyat kerajaan hidup makmur karena ditunjang oleh potensi alamnya yang memanjakan seluruh penduduk. Ketaatan rakyat pada rajanya yang dikenal arif dan bijaksana memungkinkan terciptanya keamanan dan kedamaian dalam seluruh negeri.Sedangkan nilai sejarah Buen Lajendre didapatkan dari kutipan "Dan hingga saat ini mata air Buen Lajendre tak pernah mengalami kekeringan, walau dalam musim kemarau yang amat panjang. Hal itu disebabkan karena air Buen Lajendre itu merupakan penjelmaan air mata Lalu Mangi dan Lala Ila. Sedangkan Lalu Mangi mengalami kesengsaraan yang berkepanjangan dan meninggal dunia dalam keadaan menyedihkan. Pusaranya terletak di Unter Kemang di bagian barat Desa Lantung Ai Mual." Nilai sejarah juga didapatkan pada cerita Sari Bulan yaitu mengenai asal muasal kerajaan kuno di timur Sumbawa yakni kerajaan Tangko. Kutipan yang mengandung nilai sejarah tersebut yaitu: "Singkat cerita, setelah diangkat menjadi raja, untuk mengenang jasa dan jerih payah Tangko, maka Aipad memutuskan untuk mengganti nama kerajaan menjadi kerajaan Tangko...".

Dari analisa terhadap nilai edukatif yang terkandung di dalam ketiga cerita rakyat tersebut, dapat ditarik kesimpulan bahwa ketiga cerita rakyat kaya akan nilai edukatif. Cerita rakyat Tanjung Menangis, Buen Lajendre dan Sari Bulan memiliki nilai moral, nilai adat/tradisi, nilai agama/religius, dan nilai sejarah. Secara keseluruhan, gambaran kandungan nilai edukatif ketiga cerita rakyat digambarkan dalam Gambar 1. 


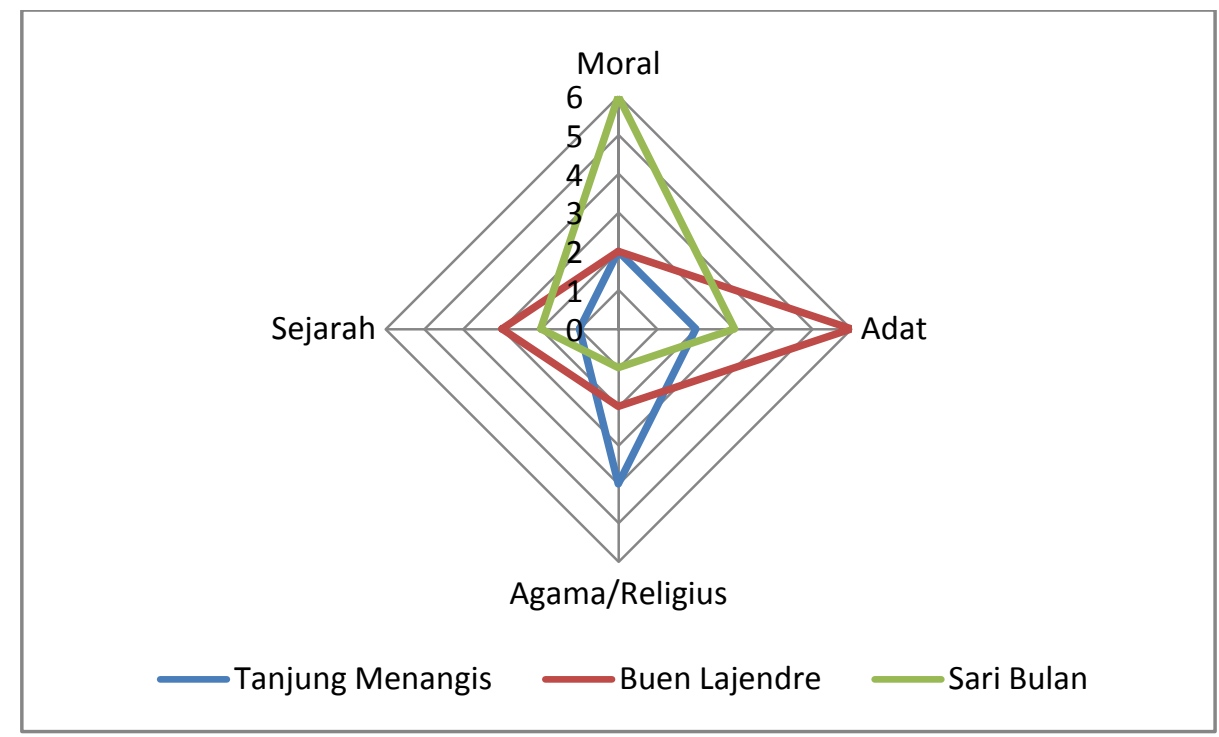

Gambar 1 Kandungan Nilai Edukatif di dalam Cerita Rakyat Tanjung Menangis, Buen Lajendre, dan Sari Bulan

Dari Gambar 1, dapat dilihat bahwa cerita rakyat Tanjung Menangis kental akan nilai agama/religius, sedangkan penulis cerita rakyat Buen Lajendre memiliki kecondongan untuk menyisipkan nilai sejarah dan nilai adat di dalam ceritanya. Berbeda dengan dua cerita lainnya, cerita rakyat Sari Bulan lebih kaya akan nilai moral dalam kehidupan manusia. Gambar 1 didapatkan dari proses analisis kutipan-kutipan di dalam cerita yang mengandung nilai-nilai edukatif. Kutipan-kutipan tersebut dimasukkan ke dalam tabel analisis nilai edukatif. Data tersebut kemudian dianalisis dengan aplikasi Ms Excel secara kuantitatif berdasar jumlah kemunculan masing-masing nilai dalam penggalan-penggalan cerita dan dipresentasikan dalam bentuk grafik radar (Gambar 1) untuk melihat kecondongan jenis nilai edukatif dalam tiap cerita.Adapun tabel yang digunakan untuk menganalisa nilai edukatif cerita rakyat ini dapat dilihat pada tabel 2. 
Tabel 2 Analisis Nilai Edukatif Cerita Rakyat Sumbawa

\begin{tabular}{|c|c|c|c|}
\hline Kandungan & \multicolumn{3}{|c|}{ Cerita Rakyat } \\
\hline Nilai Edukatif & Tanjung Menangis & Buen Lajendre & Sari Bulan \\
\hline \multirow{29}{*}{ Moral } & 1. Pesan untuk tidak & 1. Sikap hormat & 1. Pesan untuk \\
\hline & menilai orang lain & kepada orang tua yang & senantiasa meminta \\
\hline & berdasarkan tampilan & dicontohkan Lalu & restu orang tua \\
\hline & fisik semata & Mangi saat berpamitan & sebelum melakukan \\
\hline & 2. Watak Zaenal & dengan orang tua & kegiatan agar \\
\hline & Abidin yang & 2. Keramahan dan & mendapat hasil terbaik \\
\hline & mencerminkan sopan & kekeluargaan kepada & 2. Pengorbaan yang \\
\hline & dan santun dalam & tamu sebagai wujud & besar dapat muncul \\
\hline & bersikap maupun & penghormatan & sebagai buah dari rasa \\
\hline & bertutur kata. & terhadap tamu dari & sayang seperti \\
\hline & & jauh. & pengorbanan Datu \\
\hline & & & Pandai kepada istrinya \\
\hline & & & Sari Bulan. \\
\hline & & & 3. Penggambaran sikap \\
\hline & & & yang mulia dari \\
\hline & & & Tangko dalam \\
\hline & & & menolong peminta- \\
\hline & & & minta (matilla). \\
\hline & & & 4. Pesan moral bahwa \\
\hline & & & berjudi akan \\
\hline & & & memberikan dampak \\
\hline & & & buruk. \\
\hline & & & 5. Penggambaran \\
\hline & & & Aipad dan Sari Bulan \\
\hline & & & yang menunjukkan \\
\hline & & & sikap penuh syukur \\
\hline & & & dan berupaya \\
\hline & & & membalas budi baik \\
\hline & & & pada orang yang telah \\
\hline
\end{tabular}


memberikan bantuan.

6. Penggambaran Datu

Panda'i yang menerima

resiko dari

kesalahannya

7. Penggambaran

Tangko yang senang

berbagi

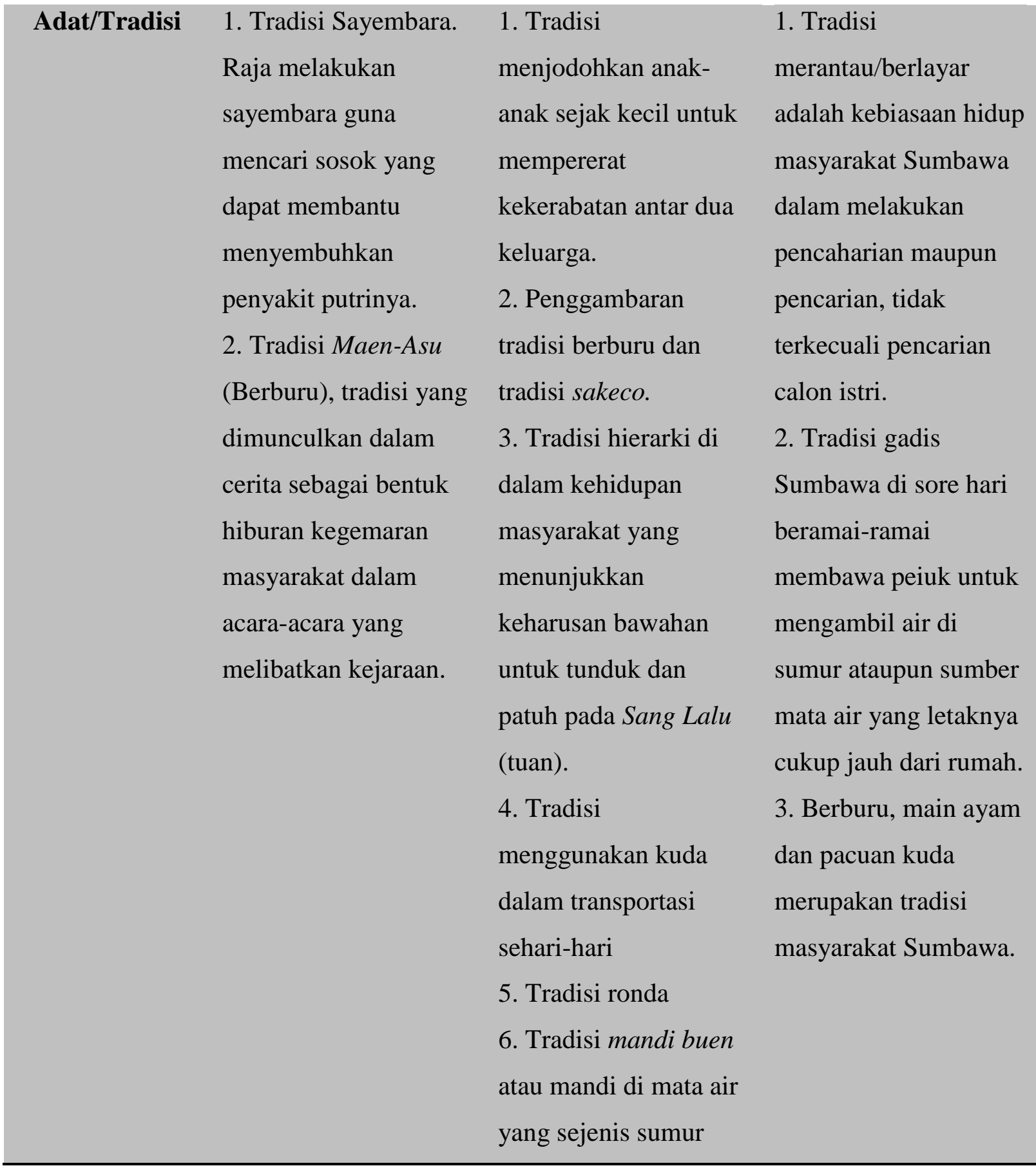


yang berada di tengah

kebun atau ladang

yang tempatnya cukup

jauh dari rumah.

Agama/Religius 1. Tokoh Zaenal

Abidin yang

digambarkan sebagai

seorang Mubaligh

Islam, murid dari

Sunan Giri yang

ditugaskan di Sulawesi

Selatan.

2. Tata cara Zaenal

Abidin dalam

melaksanakan

penyembuhan penyakit

putri Raja dengan

menggunakan ritual-

ritual keagamaan

syariat Islam.

3. Watak Zaenal

Abidin yang alim serta

tekun beribadah.

4. Ajakan Zaenal

Abidin untuk

senantiasa berserah

pada Allah SWT serta

tidak menduakanNya.
1. Penggambaran

kedua orang tua Lalu

Mangi yang

melakukan upaya

permohonan

keselamatan dan

kebaikan untuk

perjalanan Lalu Mangi

pada Tuhan. Upaya

tersebut digambarkan

dengan pemberian

azimat pada Lalu

Mangi saat melepas

kepergiannya.

2. Sikap Daeng dan

Lalu Mangi yang

menekankan sikap

usaha seorang manusia

namun tetap pasrah

pada ketetapan akhir

dari Tuhan.

\section{Kepercayaan yang}

kental masyarakat

Sumbawa sebelum

masuknya Islam yakni

menyembah makhluk-

makhluk gaib

(animisme) dengan

memberikan sesajen-

sesajen dan mantra-

matra sebagai upaya

mewujudkan hajatnya.

\begin{tabular}{llll} 
Sejarah & 1. Pendeskripsian & 1. Penceritaan sejarah & 1. Penggambaran asal \\
& Kerajaan Sumbawa & silsilah kerajaan & muasal kerajaan kuno \\
2. Pada masa awal & Sumbawa dan silsilah & di timur Sumbawa \\
\hline
\end{tabular}




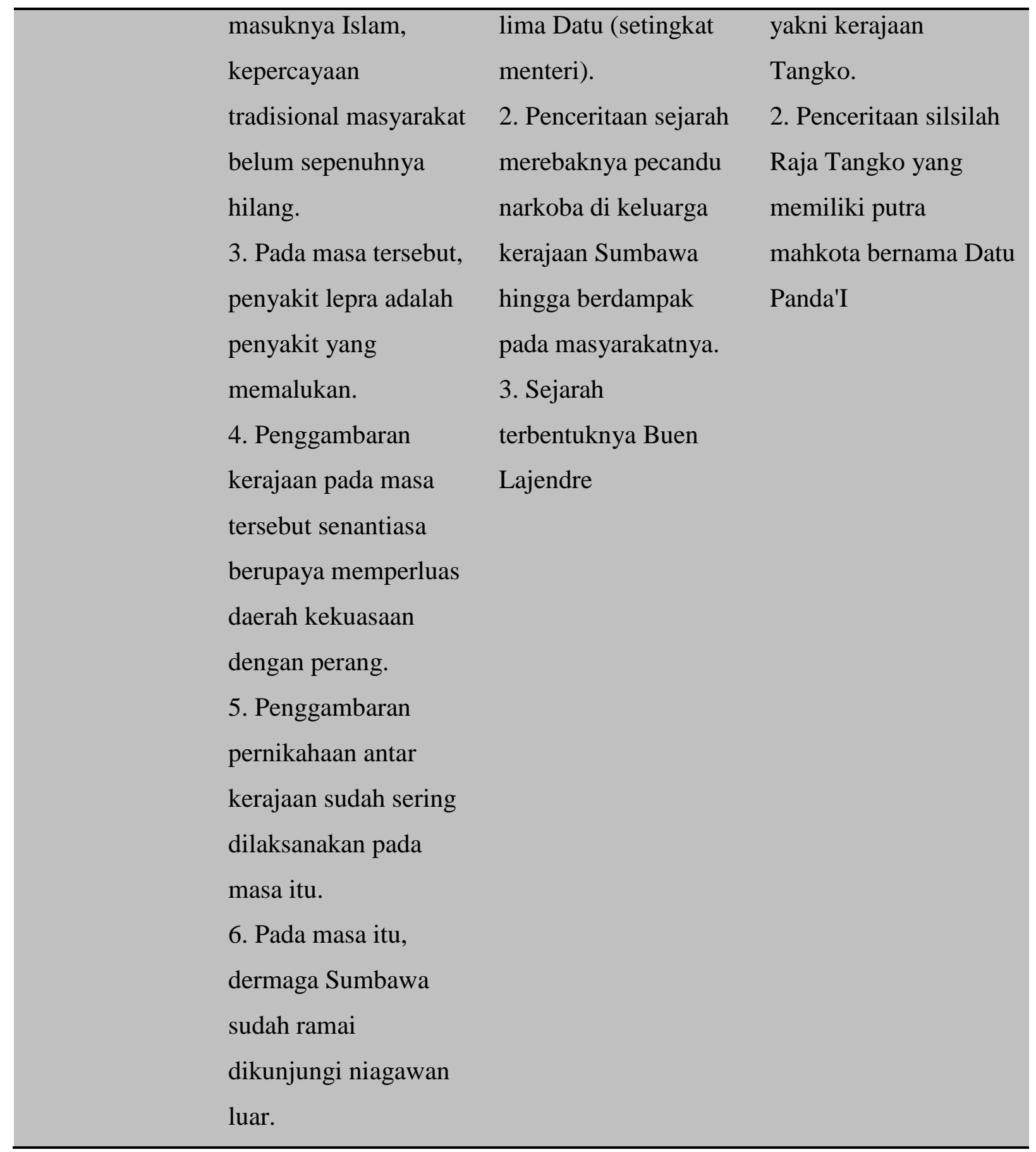

Hal ini memperjelas fungsi yang besar yang dapat dibawa oleh cerita rakyat dalam dunia pendidikan karena mengandung banyak nilai edukatif. Hal ini sesuai dengan ungkapan Bunanta (1998) bahwa nilai-nilai yang terdapat di dalam cerita rakyat tidak hanya menjadi sebuah media penghiburan, namun juga membawa manfaat lain dalam perkembangan moral, bahasa, sosial dan hal holistic. Fantasi yang dihadirkan oleh cerita rakyat dapat memicu perkembangan emosional. Cerita rakyat juga dapat mengenalkan beragam kebudayaan serta meningkatkan kematangan sastra dengan mempelajari pola narasi dalam berbahasa. 


\section{E. KESIMPULAN}

1. Struktur ketiga cerita rakyat tersebut antara lain : (1) Tema cerita rakyat Tanjung Menangis adalah legenda keagamaan, sedang Buen Lajendre dan Sari Bulan memiliki tema legenda setempat; (2) Alur cerita Tanjung Menangis adalah backtracking dan alur Buen Lajendre serta Sari Bulan adalah alur progresif; (3) Tokoh cerita Tanjung Menangis antara lain mubaligh bernama Maulana Malik Zaenal Abidin, putri raja bernama Lala Intan Bulaeng, raja, permaisuri, abdi-abdi raja, inang pengasuh Lala Intan Bulaeng, serta pasukan istana. Tokoh dalam cerita Buen Lajendre antara lain putri keturunan bangsawan yaitu Lala Ila, putra abdi kerajaan bernama Lalu Mangi, orang tua Lalu Mangi (Raden Magi dan istri), ayah Lala Ila (Datu Raden Ilung), pengawal Lalu Mangi (Salampe), Paman Lalu Mangi (Dea Angge dan istri), saudagar kain dan opium (Daeng Joge), dan inang pengasuh Lala Ila (Nini Saje). Tokoh yang terdapat di dalam Sari Bulan antara lain putra mahkota kerajaan di timur Sumbawa (Datu Panda'i), putri jelita dari negeri seberang (Sari Bulan), Kunti pelayan jin di Pulau Dewa, anak Sari Bulan dan Datu Panda'i bernama Aipad, nelayan yang baik hati bernama Tangko, Raja / orang tua Datu Panda'i, ayah dari Sari Bulan, armada Datu Panda'i, gadis-gadis di desa Sari Bulan, masyarakat kerajaan Sumbawa; (4) Latar yang menonjol pada ketiga cerita adalah latar tempat; (5) Inti amanat dari cerita Tanjung Menangis adalah pesan untuk tidak menilai seseorang dari penampilan fisiknya saja namun juga penting untuk melihat kepribadian dan kemampuannya. Amanat inti dari cerita Buen Lajendre yakni seseorang harus memiliki keteguhan sikap dan pendiriaan hingga tidak mudah terpengaruh hal-hal buruk termasuk tipu muslihat pada keburukan. Amanat dalam cerita Sari Bulan memiliki inti pesan bahwa kebenaran pada akhirnya akan menang melawan kebatilan serta pesan untuk tulus dan ikhlas dalam menolong sesama.

2. Cerita rakyat Tanjung Menangis, Buen Lajendre dan Sari Bulan memiliki nilai edukatif berupa nilai moral, nilai adat, nilai agama/religius, dan nilai sejarah yang tersirat maupun tersurat di dalam cerita. 


\section{F. SARAN}

1. Kajian nilai edukatif terhadap seluruh cerita rakyat Sumbawa sangat disarankan untuk dilakukan untuk memperkuat khasanah kebermanfaatan cerita rakyat dalam pendidikan.

2. Kajian struktural terhadap cerita rakyat akan memperkaya khasanah teori struktural cerita rakyat Sumbawa dalam dunia pendidikan.

3. Penelitian resepsi sastra cerita rakyat Sumbawa secara sinkronik maupun diakronik disarankan untuk dilakukan untuk mengetahui nilai edukatif dari cerita rakyat Sumbawa dalam pandangan banyak pelaku sastra pada satu masa maupun dari masa ke masa.

\section{DAFTAR PUSTAKA}

Abdullah, Taufik, (Ed.). 2005. Sejarah Lokal di Indonesia. Yogyakarta: Gadjah Mada University Press.

Ahmadi, Abu. dan Uhbiyati, Nur. 1991. Ilmu Pendidikan. Jakarta: PT. Rineka Cipta

Alwi, Hasan dkk. 1993. Tata Bahasa Baku Bahasa Indonesia. Edisi Kedua. Jakarta: Departemen Pendidikan dan Kebudayaan Republik Indonesia.

Aminuddin. 2004. Pengantar Apresiasi Karya Sastra. Bandung: Sinar Baru Algensindo.

Bunanta, Murti. 1998. Problematika Penulisan Cerita Rakyat Untuk Anak Indonesia. Jakarta: Balai Pustaka

Danandjaja, James. 1984. Folklor Indonesia Ilmu Gosip, Dongeng, dan lain-lain. Jakarta: Grafitipers. 2002. Folklor Indonesia: IlmuGosip, Dongengdan lain-lain. Jakarta: Pustaka Utama Grafiti.

Esten, Mursal. 1978. Kesusastraan Pengantar Teori dan Sejarah. Bandung: Angkasa Raya.

Fannie, Zainuddin. 2000. Telaah Sastra. Surakarta: Muhammadiyah University Press.

Frondizi, Risieri. 2001. Pengantar Filsafat Nilai. Yogyakarta : Pustaka Pelajar.

Harsono. 2008. Pengelolaan Perguruan Tinggi. Yogyakarta: Pustaka Pelajar

Hutomo, Suripan S.. 1991. Mutiara yang Terlupakan. Malang: Dioma.

Jabrohim. 2003. Metodologi Penelitian Sastra. Yogyakarta: Hanindita Graha

Koentjaraningrat. 2009. Pengantar Ilmu Antropologi Edisi Revisi 2009. Jakarta: Rineka Cipta.

2013. Pengantar Ilmu Antropologi Edisi Revisi 2013. Jakarta: Rineka Cipta.

Kridalaksana, Harimurti. 2011. Kamus Linguitik Edisi Keempat. Jakarta: Gramedia Pustaka Utama

Miles, M. B. dan Huberman, A.. 2007. Analisis Data Kualitatif Buku Sumber tentang Metode-Metode Baru. Terjemahan Tjetjep Rohendi Rohisi. Jakarta: Universitas Indonesia.

Mulyana. 2005. Kajian Wacana. Yogyakarta: Tiara Wacana

Nugiyantoro, Burhan. 2009. Teori Pengkajian Fiksi. Yogyakarta: Gadjah Mada University Press. 2010. Penilaian Pembelajaran Bahasa. Yogyakarta: BPFE

Nursisto. 2000. Ikhtisar Kesustraan Indonesia. Yogyakarta: Adicita Karya Nusa.

Proyek Penerbitan dan Pencatatan Kebudayaan Daerah. 1981. Cerita Rakyat Nusa Tenggara Barat (Mite dan Legenda). Mataram: Proyek Penerbitan Buku Sastra Indonesia dan Daerah.

Rusyana, Y. 1981. Cerita Rakyat Nusantara. Himpunan Makalah tentang Cerita Rakyat. Bandung: FKSS.

Sugiyono. 2016. Metode Penelitian Kuantitatif, Kualitatif dan R\&D. Bandung: PT Alfabet.

Sumarlam. 2013. Teori dan Praktik Analisis Wacana. Surakarta: Penerbit KATTA.

Suseno, Franz Magnis. 1993. Etika Dasar Masalah-masalah Pokok Filsafat Moral. Yogyakarta: Kanisius.

Teeuw, A. 1983. Sastra dan Ilmu Sastra. Jakarta: Pustaka Jaya.

Tirtaharja, Nur. 2001. Kebangkitan Nasionlisme Indonesia. Jakarta: Arya Ajisak 
UPI (Universitas Pendidikan Indonesia). 2017. Tantangan Nasionalisme Indonesia dalam Era Globalisasi. http://sejarah.upi.edu/artikel/dosen/tantangan-nasionalisme-indonesia-dalam-eraglobalisasi/. 12 Maret 2020, pk. 15.47.

Wahid, Sugira. 2004. Kapita Selekta Kritik Sastra. Makassar: Universal Negari Makassar.

Waluyo. Herman J. 1990. Teori dan Apresiasi Puisi. Jakarta:Erlangga

Zulfahnur. 1997. Teori Sastra. Bandung: Angkasa.

Zulkarnain, Aries. 2012. Legenda Tanjung Menangis. Yogyakarta: Ombak. 